Iga DROBINA ${ }^{1}$, Robert DROBINA ${ }^{2}$

Opiekun naukowy: Robert DROBINA ${ }^{2}$

DOI: https://doi.org/10.53052/9788366249837.05

\title{
OCENA BEZPIECZEŃSTWA MASZYN W ASPEKCIE \\ PROJEKTOWANIA I EKSPLOATACJI MASZYNY \\ DO SORTOWANIA ODPADÓW ZMIESZANYCH W ŚWIETLE WYMOGÓW PRAWA EUROPEJSKIEGO
}

Streszczenie: Celem pracy jest przedstawienie projektu bezpiecznej maszyny na podstawie wymogów, Norm i Dyrektyw. Projekt ten dotyczy „bezpiecznej” maszyny, która została zaprojektowana i zbudowana. W pracy przedstawiono aspekty prawne związane z projektowaniem maszyn i urządzeń oraz z zapewnieniem bezpieczeństwa pracy.

Słowa kluczowe: bezpieczna maszyna, ocena ryzyka.

\section{ASSESSMENT OF THE SAFETY OF MACHINES IN THE ASPECT OF DESIGN AND EXPLANATION OF A MIXED WASTE SORTING MACHINE IN THE LIGHT OF THE REQUIREMENTS OF EUROPEAN LAW}

\begin{abstract}
Summary: The aim of the work is to present a safe machine design based on the requirements, standards and directives. This project concerns a "safe" machine that has been designed and built. The paper presents the legal aspects related to the design of machines and devices and ensuring work safety.
\end{abstract}

Keywords: safe machine, risk assessment.

\section{Wstęp}

Bezpieczeństwo jest podstawową potrzebą człowieka. Opierając się na tym sformułowaniu, możemy śmiało stwierdzić, że bezpieczeństwo i higiena pracy jest jednym $\mathrm{z}$ podstawowych składowych $\mathrm{w}$ przedsiębiorstwie, jest również ważnym

\footnotetext{
1 Uniwersytet Śląski w Katowicach, Wydział Prawa i Administracji, email: iga.drobina@gmail.com

${ }^{2}$ dr hab. inż. prof. ATH, Akademia Techniczno-Humanistyczna w Bielsku-Białej, Wydział Budowy Maszyn i Informatyki, email: rdrobina@ath.bielsko.pl
} 
elementem zarządzania organizacją. Komfort pracownika w wykonywaniu swoich obowiązków oraz w ochronie własnego zdrowia zapewniają bezpieczne warunki pracy. Skutkuje to niższą wypadkowością w przedsiębiorstwie oraz nieobecnością spowodowaną absencją wypadkową. Dla producenta oraz pracownika podstawę bezpieczeństwa prawnego stanowią bezpieczne maszyny. Użytkownicy sprzętu spodziewają się, że oferowane są tylko pewne maszyny i urządzenia. To przeświadczenie występuje na całym świecie. W związku z tym w środowisku obowiązują uregulowania dotyczące ochrony użytkownika maszyn. Posiadają one różną problematykę w zależności od regionu. Istnieje jednak szeroko zaplanowana i przygotowana na dużą skalę zgoda dotycząca procedur stosowanych przy budowie, wyposażeniu maszyn a także eksploatacji i obsługi. W procesie oceny ryzyka przy pracy z maszynami bierze udział producent maszyn, który musi być przy ich budowie i ocenić wszystkie możliwe zagrożenia i niebezpieczne miejsca. Adekwatnie do uzyskanej oceny ryzyka wytwórca maszyny musi zlikwidować lub zmniejszyć ryzyko za pomocą odpowiednich środków. Jeśli ryzyka nie da się pozbyć za pomocą należytych metod konstrukcyjnych lub pozostałe ryzyko nie mieści się w granicach tolerancji, producent maszyny musi wybrać i zastosować odpowiednie osłony i urządzenia ochronne, a w razie potrzeby poinformować o ryzyku resztkowym. Konieczne jest wykonanie walidacji całościowej, w celu stwierdzenia, czy przewidziane środki działają prawidłowo. W procesie walidacji całościowej należy ocenić zarówno środki konstrukcyjne i techniczne, jak i związane z nimi środki organizacyjne.

Celem artykułu jest przedstawienie projektu bezpiecznej maszyny do sortowania odpadów zmieszanych w świetle wymogów prawa Europejskiego, środków ochrony pracownika określenie funkcji maszyny i zidentyfikowanie zagrożeń występujących przy jej użytkowaniu oraz oszacowanie ryzyka związanego z użytkowaniem maszyny.

\section{Bezpieczeństwo maszyn i urządzeń w świetle prawa Wspólnoty Europejskiej}

Jednym z podstawowych zamysłów Wspólnoty Europejskiej jest ochrona zdrowia obywateli, zarówno w życiu prywatnym, jak i zawodowym. Drugim podstawowym zadaniem jest stworzenie wspólnego rynku ze swobodnym przepływem towarów. Aby móc równocześnie realizować cel swobodnego przepływu towarów i ochrony obywateli, Komisja Europejska, względnie Rada Unii Europejskiej, wydała różnego rodzaju dyrektywy, które muszą być przetransponowane przez kraje członkowskie do prawa krajowego. W dyrektywach zdefiniowane są podstawowe cele i wymagania; dyrektywy mają w miarę możliwości charakter neutralny technologicznie. W dziedzinie bezpieczeństwa maszyn i ochrony pracy zostały wydane następujące dyrektywy:

- dyrektywa maszynowa, skierowana do producentów maszyn,

- dyrektywa narzędziowa,

- $\quad$ dyrektywa dotycząca użytkowania sprzętu roboczego, skierowana do użytkowników maszyn.

Dodatkowe dyrektywy, np. dyrektywa niskonapięciowa, dyrektywa w sprawie kompatybilności elektromagnetycznej, dyrektywa ATEX. Państwa członkowskie nie 
mogą zabraniać, ograniczać ani utrudniać wprowadzania do obrotu handlowego oraz uruchamiania maszyn i elementów bezpieczeństwa, które są zgodne z dyrektywą maszynową. $\mathrm{Z}$ uwagi na to nie wolno im również stawiać wyższych wymagań w zakresie właściwości maszyn i elementów bezpieczeństwa za pośrednictwem ustaw, rozporządzeń i Norm krajowych [5]. Koncepcja bezpieczeństwa maszyn w Unii Europejskiej zasadniczo polega na ustanowieniu dwóch filarów bezpieczeństwa: dla maszyn po raz pierwszy wprowadzanych na rynek Unii Europejskiej tzw. maszyn nowych i maszyn już użytkowanych, tzw. maszyn starych.

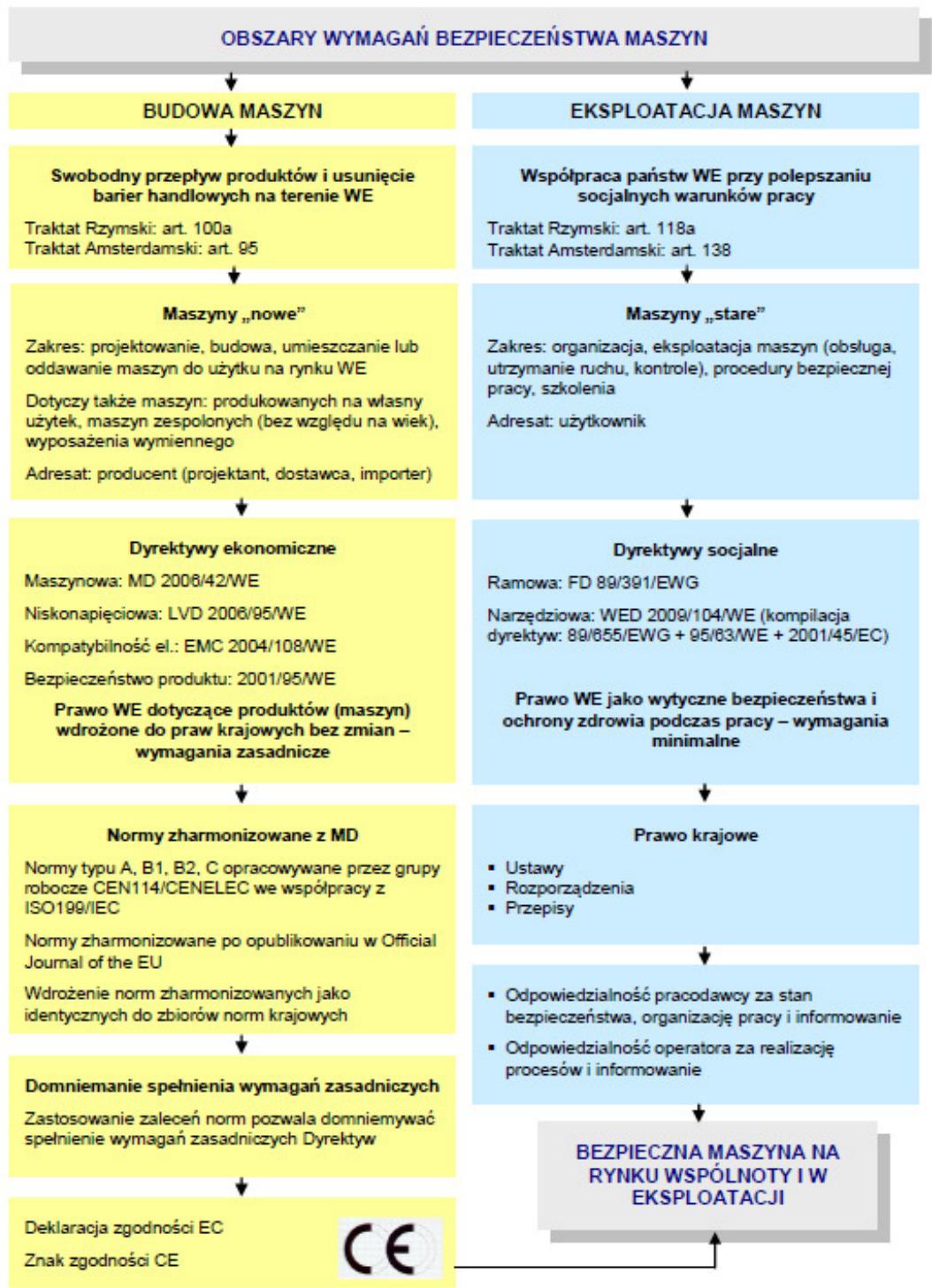

Rysunek 1. Struktura wymagań prawnych w Polsce [24] 
Koncepcja ta opiera się na wzajemnym współdziałaniu projektantów i producentów maszyn z ich użytkownikami. Konstrukcja maszyn nowych powinna zapewniać bezpieczeństwo na wysokim, określonym poziomie, natomiast maszyny stare powinny być dostosowane i utrzymywane na poziomie minimalnym (niższym niż w przypadku maszyn nowych), pozwalającym zapewnić bezpieczeństwo użytkowania. Konstrukcja maszyn nowych powinna zapewniać bezpieczeństwo na wysokim, określonym poziomie, natomiast maszyny stare powinny być dostosowane i utrzymywane na poziomie minimalnym (niższym niż w przypadku maszyn nowych), pozwalającym zapewnić bezpieczeństwo użytkowania. Dyrektywa maszynowa [1-4] skierowana jest do wszystkich podmiotów wprowadzających maszyny na rynek europejski, tj. do producentów i dystrybutorów, w tym importerów. Dotyczy ona wszystkich maszyn po raz pierwszy wprowadzanych na rynek Wspólnoty, czyli wszystkich nowych maszyn wyprodukowanych w krajach unijnych, seryjnie, jak też jednostkowo, również wytworzonych na własny użytek (tzw. samoróbek). Dotyczy też wszystkich maszyn, w tym używanych, importowanych spoza granic Unii, z tzw. krajów trzecich. W dyrektywie określono wymagania techniczne, które nazywają się wymaganiami zasadniczymi oraz procedurę dokonywania oceny zgodności maszyn z wymaganiami zasadniczymi. Dyrektywa narzędziowa [3-4] dotycząca szeroko rozumianego sprzętu roboczego, do którego zaliczamy maszyny i inne urządzenia techniczne, narzędzia, instalacje oraz sprzęt do tymczasowej pracy na wysokości. Głównym adresatem dyrektywy są użytkownicy wymienionego sprzętu, czyli pracodawcy. W dyrektywie narzędziowej określono najniższe dopuszczalne wymagania techniczne, tzw. wymagania minimalne w odniesieniu do użytkowanego (starego) sprzętu roboczego, a także określono wymagania związane $\mathrm{z}$ bezpieczeństwem użytkowania zarówno nowego, jak i starego sprzętu. Należy podkreślić, że minimalne wymagania techniczne mogą dotyczyć także nowego sprzętu roboczego nieobjętego postanowieniami dyrektywy maszynowej i innych dyrektyw nowego podejścia (dyrektyw ekonomicznych) [1-2], np. proste narzędzia ręczne, drabina itp.

\section{Bezpieczeństwo maszyn i urządzeń w świetle technicznych środków ochrony}

Podejście projektowe jest pierwszym i najważniejszym etapem w procesie zmniejszania ryzyka. Możliwe zagrożenia wyklucza się w tym przypadku już na etapie projektowania i konstrukcji. Aspekty bezpiecznego projektu dotyczą konstrukcji samej maszyny oraz interakcji pomiędzy zagrożonymi osobami i maszyną. Podstawowym zadaniem przy projektowaniu jest niedopuszczanie do powstawania jakichkolwiek zagrożeń. Uzyskuje się to na przykład poprzez: unikanie ostrych krawędzi, kątów i wystających elementów, unikanie miejsc grożących zgnieceniem, otarciem i wciągnięciem, ograniczenie energii kinetycznej (masa i prędkość), przestrzeganie zasad ergonomii. W każdym przypadku należy wybrać, zastosować i dopasować wszystkie elementy składowe w taki sposób, aby w przypadku błędu w maszynie bezpieczeństwo ludzi miało najwyższy priorytet [1-2]. Należy też uwzględnić unikanie szkód w maszynie i w otoczeniu. Specyfikację wszystkich części składowych maszyny należy określić w taki sposób, aby działały one w obrębie dopuszczalnych wartości granicznych. Zasadniczo budowa powinna 
być wykonana w najprostszy możliwy sposób. Funkcje związane z bezpieczeństwem należy w miarę możliwości oddzielić od innych w maksymalnym możliwym zakresie.

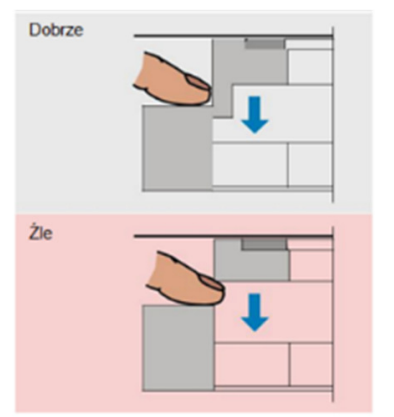

Rysunek 2. Przykład unikania miejsc grożacego skaleczeniem [25]

Techniczne środki ochronne przed zagrożeniami mechanicznymi dzielimy na: osłony oraz urządzenia ochronne. Poprawny dobór technicznego środka ochronnego powinien być dokonany na podstawie oceny ryzyka w odniesieniu do konkretnej maszyny. Przy doborze należy uwzględnić kryterium umiejscowienia i konieczność dostępu do strefy nie bezpiecznej. Z zagrożeniami mechanicznymi (ruchomymi elementami) mamy do czynienia w dwóch obszarach: w strefie przekazania napędu i strefie pracy narzędzia (tzw. Strefie roboczej) [5].

\section{Osłony}

Osłona to część maszyny stanowiąca fizyczną zaporę przeznaczoną do zapewnienia ochrony, zwłaszcza przed czynnikami mechanicznymi. W zależności od konstrukcji osłona może być nazywana obudową, pokrywą, ekranem, drzwiami, barierą, przegrodą itp. Osłona która jest połączona $\mathrm{z}$ maszyną na stałe, np. przyspawana lub połączona za pomocą elementów mocujących, których nie można usunąć bez pomocy narzędzia (np. śruba, nakrętka) jest osłoną stałą. Osłona stała jest prostym i skutecznym urządzeniem i dlatego powinna być stosowana wszędzie tam gdzie dostęp operatora w czasie normalnej pracy (działania bez zakłóceń) nie jest konieczny. Jeżeli natomiast występuje konieczność częstego dostępu, oznaczająca konieczność demontażu osłony, to jest bardzo prawdopodobne, że nie powróci ona na swoje miejsce. W takich przypadkach należy zastosować inny alternatywny środek ochronny w postaci osłony ruchomej lub czułego wyposażenia ochronnego. Podstawową zasadą ochrony przy wykorzystaniu osłon jest ograniczanie do minimum dostępu do stref zagrożenia. W tym celu, tam gdzie jest to technicznie możliwe, należy tak projektować maszyny i osłony, aby czynności regulacji, smarowania i konserwacji były możliwe do wykonania bez otwierania lub zdejmowania osłon. Wszystkie osłony powinny znajdować się w takiej od ległości od elementów niebezpiecznych, aby człowiek nie miał bezpośredniej możliwości dotknięcia tych elementów, zarówno przez otwory w osłonie (osłona niepełna) jak też nad, pod czy też obok konstrukcji osłony. Minimalna odległość w jakiej powinna być utytułowana osłona (konstrukcja ochronna) od elementów niebezpiecznych nazywana jest odległością bezpieczeństwa. Odległości bezpieczeństwa zostały określone w „PN-EN ISO 13857 Bezpieczeństwo maszyn - Odległości bezpieczeństwa uniemożliwiające sięganie kończynami górnymi i dolnymi do stref niebezpiecznych", która zastąpiła dwie Normy 
PN-EN 294 i PN-EN 811. Punktem wyjścia do wyliczenia odległości bezpieczeństwa jest ocena ryzyka. Przykładowo za ryzyko małe uznajemy ryzyko otarcia lub starcia, a za ryzyko duże - ryzyko pochwycenia. W procesie planowania i konstruowania maszyny należy przeanalizować możliwe ryzyko i w razie potrzeby przewidzieć środki ochrony operatora przed istniejącymi zagrożeniami. Pomocą dla producenta maszyn przy wypełnianiu tego zadania są Normy, które definiują i opisują proces oceny ryzyka. Ocena ryzyka jest efektem kroków logicznych, umożliwiających systematyczną analizę i ocenę ryzyka. Maszyna musi być zaprojektowana i wykonana przy uwzględnieniu wyników oceny ryzyka. Jeśli to konieczne, ocena ryzyka pociąga za sobą zmniejszenie ryzyka poprzez zastosowanie odpowiednich środków ochronnych. Zastosowanie środków ochronnych nie może spowodować powstania nowego ryzyka. Powtórzenie całej procedury, tj. oceny i zmniejszenia ryzyka, może być konieczne $\mathrm{w}$ celu maksymalnego możliwego wyeliminowania zagrożeń i dostatecznego zmniejszenia rozpoznanego lub nowego ryzyka. $\mathrm{W}$ wielu Normach typu $\mathrm{C}$ podana jest ocena ryzyka w odniesieniu do maszyn i procesów. Jeśli nie ma możliwości zastosowania Norm typu C lub są one niewystarczające, można wykorzystać przepisy podane w Normach typu A i B [5].

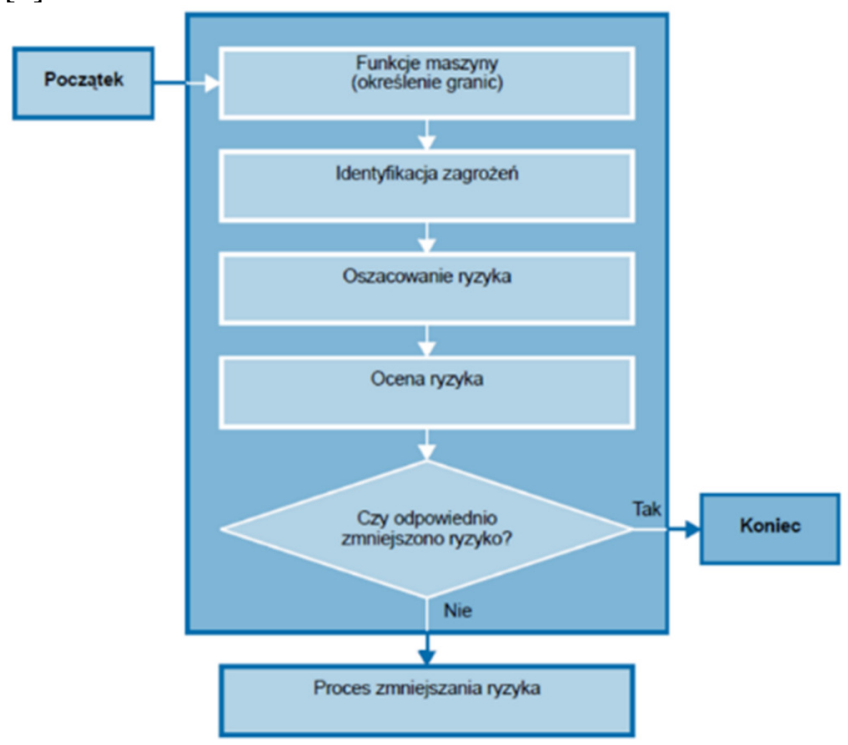

Rysunek 3. Proces oceny ryzyka [26]

Procedurę należy wykonać dla wszystkich zagrożeń. Należy ją powtarzać (proces iteracyjny) tak długo, aż pozostałe ryzyko resztkowe będzie małe i możliwe do zaakceptowania. Uzyskane wyniki oceny ryzyka i zastosowaną procedurę należy udokumentować.

\section{Określenie funkcji maszyny}

Pierwszym etapem procesu oceny ryzyka jest określenie funkcji maszyny przykładem mogą być informacje takie jak [5]:

- specyfikacja maszyny (co jest produkowane, maksymalna wydajność produkcji), 
- granice przestrzenne i przewidywane miejsce zastosowania,

- planowany okres użytkowania (trwałość użytkowa),

- planowane funkcje i tryby pracy,

- $\quad$ spodziewane nieprawidłowe działania i awarie,

- $\quad$ odruchowe działanie ludzi w przypadku nieprawidłowego działania,

- produkty mające związek z maszyną,

- $\quad$ nieprawidłowe zachowanie z powodu braku koncentracji,

- użytkowanie zgodne z przeznaczeniem, a także niezamierzone działania operatora lub możliwe do przewidzenia.

Identyfikacja zagrożeń mechanicznych

Kolejnym etapem procesu oceny ryzyka jest identyfikacja zagrożeń, jest to systematyczna ocena możliwych do przewidzenia zagrożeń, niebezpiecznych sytuacji lub zdarzeń.

Producent urządzeń powinien uwzględnić zagrożenia, przykładem mogą być, [2-3], [5]:

- zagrożenia mechaniczne takie jak: przecięcie, odcięcie, wciągniecie, pochwycenie, zmiażdżenie, ukłucie, uderzenie,

- $\quad$ zagrożenia elektryczne takie jak: porażenie, poparzenie, wstrząs, szok, zagrożenia termiczne takie jak: oparzenie, sparzenie, odwodnienie, dyskomfort,

- zagrożenia powodowane hałasem takie jak: utrata równowagi, utrata świadomości, stres, zmęczenie, szum w uszach,

- $\quad$ zagrożenia powodowane drganiami mechanicznymi takie jak: dyskomfort, schorzenia lędźwi, schorzenia neurologiczne, urazy kręgosłupa,

- zagrożenia powodowanie promieniowaniem takie jak: oparzenia, uszkodzenia wzroku i skóry, mutacje genetyczne, ból głowy, bezsenność, zagrożenia powodowane materiałami lub substancjami takie jak: trudności w oddychaniu, choroby (nowotwory), zatrucia, infekcje, wybuch, pożar, ogień,

- zagrożenia powodowane nieprzestrzeganiem zasad ergonomii takie jak: dyskomfort, zmęczenie, stres, zburzenia układu mięśniowo-szkieletowego, zagrożenia wynikające ze środowiska w którym maszyna jest użytkowana takie jak: oparzenia, poślizgnięcie, upadek, duszenie się.

\section{Szacowanie ryzyka przy obsłudze maszyn - Projekt}

Po zidentyfikowaniu zagrożeń należy przeprowadzić szacowanie ryzyka dla każdej niebezpiecznej sytuacji. Do oszacowania poziomu ryzyka i określania cech urządzeń ochronnych gwarantujących skuteczność nadzorowania zidentyfikowanych zagrożeń, zastosowano metodę WPR (Wskaźnik Poziomu Ryzyka). Wskaźnik WPR, szacowany dla każdego zidentyfikowanego zagrożenia (czynnik, sytuacja, zdarzenie/skutki), jest kombinacją przewidywanej ciężkości strat (uraz, straty materialne), ekspozycji (czas, częstość narażeń) i skuteczności nadzorowania zagrożeń [1-2],[5]:

$$
W P R=S \cdot E \cdot P,
$$

gdzie: S - uraz określa potencjalne skutki zagrożeń. 
Wskaźnik jest wypadkową ciężkości i umiejscowienia urazu z jednoczesnym oszacowaniem strat materialnych (tab. 1), E - ekspozycja - czas/częstość narażeń (tab. 2), P - poziom skuteczności nadzorowania zagrożeń (tab. 3), WPR - wskaźnik ryzyka tj. wartość liczbowa (waga), wg której jest dokonywane szacowanie poziomu ryzyka.

Tabela 1. Wskaźnik ciężkości urazu [12]

\begin{tabular}{|c|c|}
\hline \multicolumn{2}{|r|}{ S- wskaźnik ciężkości urazu } \\
\hline $\begin{array}{c}\text { Wskaźnik } \\
\text { ciężkości } \\
\text { urazu S }\end{array}$ & Straty ludzkie/ materialne \\
\hline 10 & $\begin{array}{l}\text { ekstremalnie nieodwracalny: śmierć; bardzo ciężkie urazy } 1 \text { lub kilku osób } \\
\text { - utrata wzroku, kończyn, ciężkie i rozległe poparzenia i in. łącznie ze } \\
\text { śmiercią - długa i intensywna pomoc szpitalna i rehabilitacja, ciągła opieka } \\
\text { medyczna i społeczna - renta inwalidzka, brak możliwości podjęcia działań } \\
\text { zawodowych }\end{array}$ \\
\hline 7 & $\begin{array}{l}\text { nieodwracalny: ciężkie uszkodzenia ciała powodujące trwałe kalectwo - } \\
\text { zmiażdżenia, amputacje, rozległe poparzenia II stopnia, porażenie układu } \\
\text { nerwowego i mięśniowo -szkieletowego, utrata wzroku, słuchu, zatrucia } \\
\text { i in. - długa i intensywna pomoc szpitalna i rehabilitacja - renta inwalidzka, } \\
\text { możliwość podjęcia działań zawodowych w ograniczonym zakresie }\end{array}$ \\
\hline 5 & $\begin{array}{l}\text { częściowo nieodwracalny: ciężkie wielokrotne złamania, miejscowe } \\
\text { porażenie układu mięśniowo-szkieletowego, amputacje, miejscowe } \\
\text { poparzenia II stopnia, uszkodzenie wzroku lub słuchu - absencja powyżej } \\
3 \text { miesięcy }\end{array}$ \\
\hline 3 & $\begin{array}{l}\text { odwracalny: np. złamanie kości, nieznaczna amputacja części ciała, } \\
\text { miejscowe poparzenia I stopnia, ciężkie stłuczenia, czasowe zatrucia - } \\
\text { pomoc szpitalna i ograniczona rehabilitacja - absencja do } 3 \text { miesięcy }\end{array}$ \\
\hline 1 & $\begin{array}{l}\text { Odwracalny: np. skaleczenie, przekłucie, przebicie, lekkie stłuczenie, } \\
\text { starcie/otarcie, oparzenie - udzielenie pierwszej pomocy na terenie zakładu } \\
\text { pracy bez absencji }\end{array}$ \\
\hline
\end{tabular}

Tabela 2. Wskaźnik ekspozycji (częstość występowania) [12]

\begin{tabular}{|c|l|}
\hline \multicolumn{1}{|c|}{$\begin{array}{c}\text { Wskaźnik } \\
\text { ekspozycji E }\end{array}$} & \multicolumn{1}{c|}{ Czas/częstość natężenia na zagrożenie } \\
\hline 10 & Bardzo częsta do ciągłej (częściej niż 1 raz na godzinę) \\
\hline 6 & $\begin{array}{l}\text { Częsta-codzienna (częściej niż 1 raz na zmianę lub jednorazowo dłużej niż } \\
15 \text { minut) }\end{array}$ \\
\hline 5 & $\begin{array}{l}\text { Dosyć częsta (rzadziej niż 1 raz na zmianę lub jednorazowo krócej niż 15 } \\
\text { minut) }\end{array}$ \\
\hline 3 & Sporadyczna (np. średnio raz w tygodniu) \\
\hline 2 & Okazjonalna (np. średnio raz w miesiącu) \\
\hline 1 & Minimalna (np. średnio raz w roku) \\
\hline
\end{tabular}


Tabela 3. Prawdopodobieństwo wystapienia zdarzenia [12]

\begin{tabular}{|c|c|c|}
\hline \multicolumn{3}{|c|}{$\begin{array}{c}P \text { - prawdopodobieństwo zaistnienia zdarzenia wypadkowego } \\
\text { (poziom skuteczności nadzorowania zagrożeń) }\end{array}$} \\
\hline $\begin{array}{c}\text { Wskaźnik } \\
\text { prawdopodobieństwa } \\
\mathrm{P}\end{array}$ & $\begin{array}{l}\text { Możliwość } \\
\text { zaistnienia } \\
\text { zdarzenia }\end{array}$ & Poziom skuteczności \\
\hline 10 & $\begin{array}{c}\text { Bardzo } \\
\text { prawdopodobne }\end{array}$ & $\begin{array}{l}\text { Bardzo niski ze względu na brak urządzeń } \\
\text { ochronnych. Brak możliwości uniknięcia lub } \\
\text { ograniczenia szkód }\end{array}$ \\
\hline 5 & Prawdopodobne & $\begin{array}{l}\text { Bardzo niski ze względu na brak urządzeń } \\
\text { ochronnych. Możliwość uniknięcia lub } \\
\text { ograniczenia szkód }\end{array}$ \\
\hline 3,5 & $\begin{array}{l}\text { Mało } \\
\text { prawdopodobne } \\
\text { ale możliwe }\end{array}$ & $\begin{array}{l}\text { Niski ze względu na nieodpowiedni dobór } \\
\text { urządzeń do nadzorowania rozpatrywanych } \\
\text { sytuacji zagrożenia, źle dobrane odległości } \\
\text { bezpieczeństwa, niewystarczającą KAT / PL } \\
\text { sterowania }\end{array}$ \\
\hline 3 & $\begin{array}{l}\text { Mało } \\
\text { prawdopodobne } \\
\text { ale możliwe }\end{array}$ & $\begin{array}{l}\text { Niski ze względu na nieodpowiedni dobór } \\
\text { urządzeń do nadzorowania rozpatrywanych } \\
\text { sytuacji zagrożenia, źle dobrane odległości } \\
\text { bezpieczeństwa, niewystarczającą KAT / PL } \\
\text { t } \llbracket \text { row } \square \text {; Nadzorowanie skuteczniejsze niż dla } \\
\text { A=3,5 }\end{array}$ \\
\hline 2,5 & $\begin{array}{l}\text { Mało } \\
\text { prawdopodobne } \\
\text { ale możliwe }\end{array}$ & $\begin{array}{l}\text { Średni ze względu na nieodpowiedni dobór } \\
\text { urządzeń do nadzorowania rozpatrywanych } \\
\text { sytuacji zagrożenia, źle dobrane odległości } \\
\text { bezpieczeństwa, niewystarczającą KAT / PL } \\
\text { sterowania }\end{array}$ \\
\hline 1 & $\begin{array}{l}\text { Bardzo mało } \\
\text { prawdopodobne } \\
\text { ale możliwe }\end{array}$ & $\begin{array}{l}\text { Wysoki ze względu na zastosowanie skutecznych } \\
\text { urządzeń ochronnych i odpowiedniej KAT/PL. } \\
\text { Brak nadzorowania dostępu do strefy osób } \\
\text { 3-ch.Brak piktogramów ostrzegawczych i } \\
\text { procedur bezpiecznej pracy }\end{array}$ \\
\hline 0,7 & $\begin{array}{l}\text { Możliwe tylko } \\
\text { sporadycznie }\end{array}$ & $\begin{array}{l}\text { Wysoki ze względu na zastosowanie skutecznych } \\
\text { urządzeń ochronnych i odpowiedniej KAT/PL. } \\
\text { Brak nadzorowania dostępu do strefy osób } \\
\text { trzecich. Są piktogramy ostrzegawcze } \\
\text { i pro } \square \text { dury b } \square \text { pi } \square \| \text { j pr } \square \text { y; J J odpowi } \square \square \\
\text { nadzór nad personelem, organizacja stanowiska } \\
\text { roboczego i zadań. }\end{array}$ \\
\hline 0,5 & $\begin{array}{l}\text { Możliwe tylko } \\
\text { sporadycznie }\end{array}$ & $\begin{array}{l}\text { Wysoki ze względu na zastosowanie skutecznych } \\
\text { urządzeń ochronnych i odpowiedniej KAT/PL } \\
\text { nadzorowany dostęp osób trzecich }\end{array}$ \\
\hline 0,1 & $\begin{array}{l}\text { Możliwe tylko } \\
\text { teoretycznie }\end{array}$ & $\begin{array}{l}\text { Bardzo wysoki ze względu bezpieczne prędkości } \\
\text { liniowe } \mathrm{v}(\mathrm{mm} / \mathrm{s}) \text { - wynikające z konstrukcji } \\
\text { elementów niebezpiecznych pozwalające na } \\
\text { niedopuszczenie do zdarzeń zagrażających } \\
\text { (wynikające z normalnej pracy maszyny) }\end{array}$ \\
\hline 0,05 & $\begin{array}{l}\text { Możliwe tylko } \\
\text { teoretycznie }\end{array}$ & 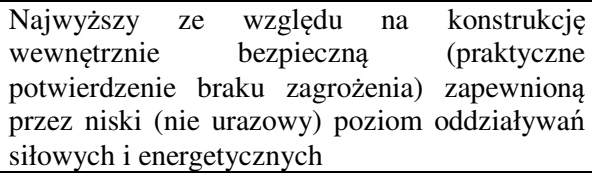 \\
\hline
\end{tabular}


Kryteria akceptowalności poziomu ryzyka przedstawione zostały w tab. 4

Tabela 4. Poziomy akceptowalności ryzyka [12]

\begin{tabular}{|c|c|c|c|c|}
\hline $\begin{array}{c}\text { Poziom } \\
\text { ryzyka }\end{array}$ & $\begin{array}{c}\text { Wskaźnik } \\
\text { poziomu } \\
\text { ryzyka } \\
\text { [WPR] }\end{array}$ & $\begin{array}{c}\text { Ocena } \\
\text { poziomu } \\
\text { ryzyka }\end{array}$ & $\begin{array}{c}\text { Akceptowalność } \\
\text { ryzyka }\end{array}$ & Zalecane działania \\
\hline 1 & $\mathrm{WPR} \leq 20$ & $\begin{array}{l}\text { Bardzo } \\
\text { niskie }\end{array}$ & Akceptowalne & $\begin{array}{l}\text { Działania doraźne nie są } \\
\text { potrzebne. } \\
\text { i okresowe monitorowanie } \\
\text { stanu Codzienne } \\
\text { Procedury bezpiecznej pracy. } \\
\text { Szkolenia }\end{array}$ \\
\hline 2 & $20<\mathrm{WPR} \leq 70$ & Niskie & Akceptowalne & $\begin{array}{lr}\text { Zwiększona } & \text { czujność przy } \\
\text { codziennych i } & \text { okresowych } \\
\text { kontrolach } & \text { stanu } \\
\text { bezpieczeństwa. Procedury } \\
\text { bezpiecznej pracy. Szkolenia. } \\
\text { (Zaleca się rozważenie } \\
\text { możliwości redukcji ryzyka } \\
\text { do poziomu bardzo niskiego }\end{array}$ \\
\hline 3 & $70<\mathrm{WPR} \leq 110$ & Średnie & $\begin{array}{l}\text { Akceptowalne } \\
\text { warunkowo }\end{array}$ & 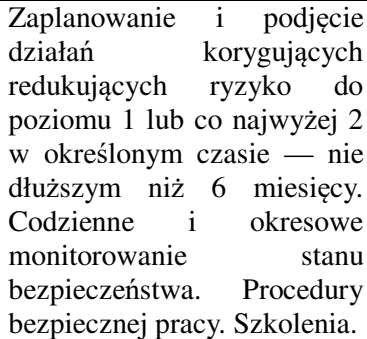 \\
\hline 4 & $\begin{array}{c}110<\mathrm{WPR} \leq 18 \\
0\end{array}$ & Średnie & $\begin{array}{l}\text { Akceptowalne } \\
\text { warunkowo }\end{array}$ & 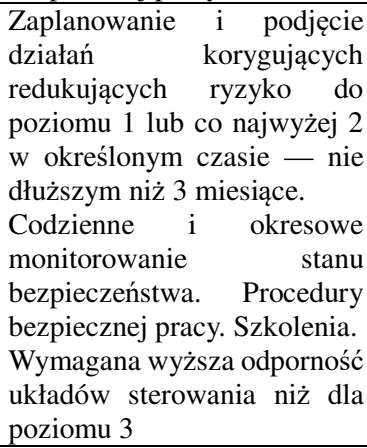 \\
\hline 5 & $\begin{array}{c}180<\mathrm{WPR} \leq 30 \\
0\end{array}$ & Wysokie & Nieakceptowalne & $\begin{array}{l}\text { Podjęcie natychmiastowych } \\
\text { działań naprawczych przy } \\
\text { realizacji prac bieżących } \\
\text { redukujących ryzyko do } \\
\text { poziomu akceptowalnego } \\
1 \text { lub co najwyżej } 2 \text {. } \\
\text { Odłożenie prac planowanych } \\
\text { do czasu redukcji ryzyka }\end{array}$ \\
\hline
\end{tabular}




\begin{tabular}{|c|c|c|l|l|}
\hline 6 & $300<$ WPR $\leq 50$ & Bardzo & Nieakceptowalne & $\begin{array}{l}\text { Natychmiastowe wstrzymanie } \\
\text { prac i podjęcie działań } \\
\text { naprawczych redukujących } \\
\text { ryzyko do poziomu } \\
\text { akceptowalnego 1 lub co } \\
\text { najwyżej 2 }\end{array}$ \\
\hline 7 & $500<$ WPR & Bardzo & Nieakceptowalne & $\begin{array}{l}\text { Natychmiastowe wstrzymanie } \\
\text { prac i podjęcie działań } \\
\text { naprawczych redukujących } \\
\text { ryzyko do poziomu } \\
\text { akceptowalnego 1 lub co } \\
\text { najwyżej 2. Wymagana } \\
\text { wyższa odporność układów } \\
\text { sterowania niż dla poziomu nr } \\
6\end{array}$ \\
& &
\end{tabular}

\section{Bezpieczeństwo maszyny do segregowania odpadów zmieszanych - poziom zapewnienia bezpieczeństwa w oparciu o Normę EN ISO 13849 Bezpieczeństwo maszyn}

W ramach artykułu przeprowadzono ocenę ryzyka zawodowego i ocenę bezpieczeństwa maszyny na stanowisku operatora maszyny segregującej w świetle obowiązujących Dyrektyw Maszynowych [3-4]. Ocenę ryzyka dokonano metodą Risk score. Pierwszym krokiem dostosowania maszyny jest identyfikacja - określenie działania maszyny oraz jej danych konstrukcyjnych. Urządzenie bazuje na zastosowaniu i połączniu w ruchu ciągłym taśmociągów oraz specjalnej konstrukcji wialni. Schemat ideowy zasady działania urządzenia przedstawiono na rys.4.

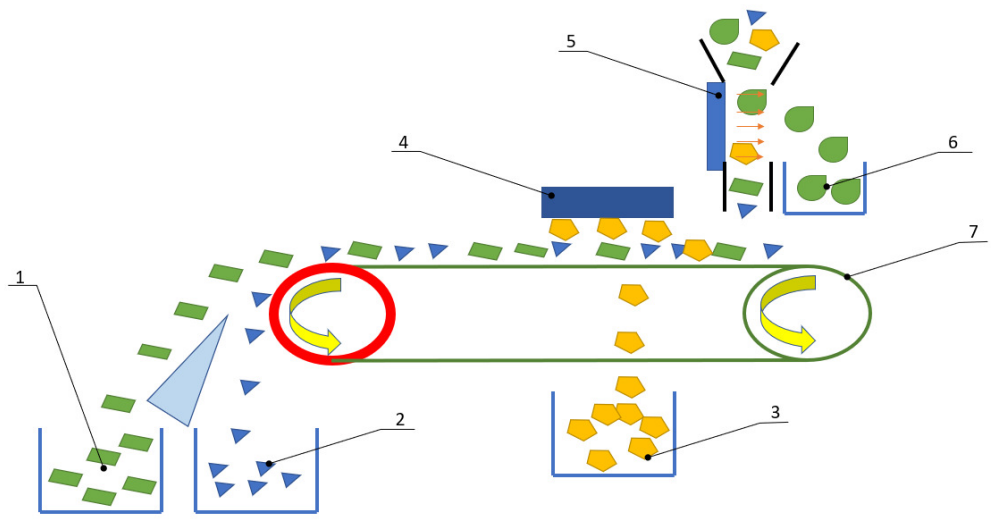

Rysunek 4. Schemat działania segregowania odpadów zmieszanych: 1-pojemnik na odpady aluminiowe, 2- pojemnik na odpady plastikowe, 3-pojemnik na odpady stalowe, 4- taśmociag pomocniczy, 5-wialnia, 6- pojemnik na odpady styropianowe, 7- taśmociąg główmy

Przedstawiona na rys.4. maszyna przeznaczona do segregacji odpadów wyposażona jest $\mathrm{W}$ wialnię (5) służącą do oddzielenia $\mathrm{z}$ wymieszanych frakcji styropianu, 
aluminium, plastiku, stali tylko styropianu i podaniu go do pojemnika na styropian (6), pozostałe frakcje opadają grawitacyjnie na taśmociąg główny (7), na taśmociągu głównym (7) zamocowany jest nad nim w poprzek taśmociąg pomocniczy (4), którego zadaniem jest oddzielenie frakcji metalowych z taśmociągu głównego (7) i następnie podanie ich do pojemnika na elementy stalowe (3), na końcu taśmociągu głównego zostaje wytworzone zmienne pole magnetyczne którego zadaniem jest odseparowanie ostatniej frakcji a mianowicie rozdzielenie aluminium i podanie go do pojemnika (1) od plastiku który opadnie do pojemnika (2). Separator odpadów zmieszanych oddziela materiały ferromagnetyczne i nieferromagnetyczne tworzywa sztuczne i materiały lekkie. Maszyna pracując wykorzystuje pęd powietrza, pole magnetyczne oraz zjawisko prądów wirowych. Separator wyposażony jest w następujące konstrukcje:

- Wialnię, w której zastosowano wentylator sztucznie wytwarzający pęd powietrza dzięki któremu można oddzielić frakcję lekką taką jak styropian od pozostałych materiałów.

- Taśmociąg pomocniczy wykorzystujący pole magnetyczne powstałe na skutek magnesów neodymowych, który przyciąga materiały ferromagnetyczne na przykład stal.

Główny taśmociąg pełniący funkcję separatora materiałów nieferromagnetycznych takich jak miedź czy aluminium, jego działanie możliwe jest dzięki pracy rotora magnetycznego, do którego przymocowane są magnesy neodymowe. Są one zamocowane do drewnianego wałka obracającego się z prędkością $3000 \mathrm{obr} / \mathrm{min}$ Magnesy ułożone są naprzemiennie północ południe. Dzięki takiemu ulokowaniu wytwarza się prąd wirowy, który indukuje się w materiałach nieferromagnetycznych. Dzięki temu tworzy się napięcie tworzące pole elektromagnetyczne odrzucające frakcję.

$\mathrm{Na}$ rysunku 5 przedstawiono kompletną maszynę do sortowania odpadów zmieszanych wraz z układem sterowania i systemami bezpieczeństwa.

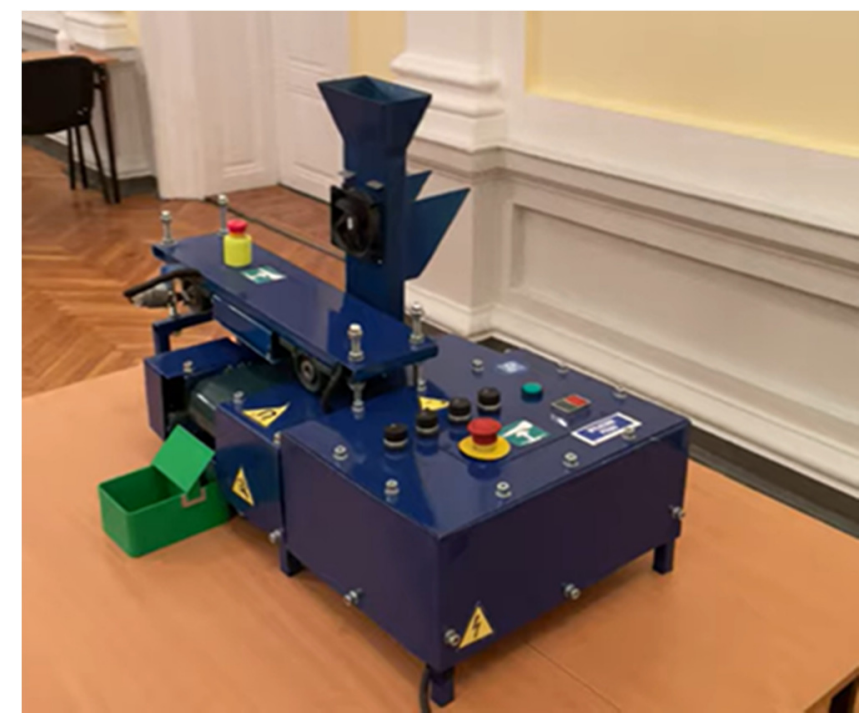

Rysunek 5. Maszyna do sortowania odpadów zmieszanych 
Układ sterowania maszyny wraz ze wszelkimi elementami wchodzącymi w jego skład jest odpowiedzialny za wykonywanie zarówno funkcji technologicznych jak też funkcji bezpieczeństwa. Dlatego też elementy systemu sterowania związane $\mathrm{z}$ bezpieczeństwem powinny być niezawodne, tj. dobierane $\mathrm{z}$ uwzględnianiem możliwych uszkodzeń, defektów oraz ograniczeń, jakie można przewidzieć w planowanych warunkach użytkowania maszyny. Układ sterowania powinien wykluczyć niebezpieczne działanie maszyny i zapewnić zachowanie funkcji bezpieczeństwa przy wszystkich rodzajach pracy. Z reguły w Normach C podany jest wymagany poziom bezpieczeństwa. Wymagany poziom bezpieczeństwa należy określić oddzielnie dla każdej funkcji bezpieczeństwa; obowiązuje on wówczas dla wszystkich zastosowanych urządzeń, takich jak np.:

czujnik/urządzenie ochronne, analizujący moduł logiczny, element wykonawczy/elementy wykonawcze. Jeśli dla odpowiedniej maszyny brak Normy C nie istnieją odnośne dane, wymagany poziom bezpieczeństwa można określić w oparciu o Normę EN ISO 13849. Poprzez zastosowanie Normy zapewnia się odpowiedni stosunek nakładów na realizację do stwierdzonego ryzyka. Ochrona operatora wkładającego lub wyjmującego ręcznie elementy do lub z prasy do metalu wymaga innego potraktowania niż ochrona operatora pracującego przy maszynie, przy której maksymalnym ryzykiem jest zakleszczenie palca. Ponadto, w różnych fazach eksploatacji tej samej maszyny mogą występować różne miejsca zagrożenia o różnym ryzyku. W takim przypadku należy oddzielnie określić funkcje bezpieczeństwa dla każdej fazy eksploatacji i każdego zagrożenia.

Podstawą dla wszystkich Norm są następujące parametry do oceny ryzyka: stopień możliwego uszkodzenia ciała/uszczerbku na zdrowiu częstotliwość i czas trwania zagrożenia możliwość uniknięcia zagrożenia. Połączenie parametrów określa wymagany poziom bezpieczeństwa. W przypadku stosowania procedur do określania poziomu bezpieczeństwa, opisanych w wyżej wymienionych Normach, maszyna jest rozpatrywana bez urządzeń ochronnych. W tej Normie do określania wymaganego poziomu bezpieczeństwa stosuje się także graf ryzyka, do określenia wielkości ryzyka wykorzystuje się te same parametry S, F oraz P. Wynikiem procesu jest: wymagany poziom bezpieczeństwa PLr (requiered performance level).

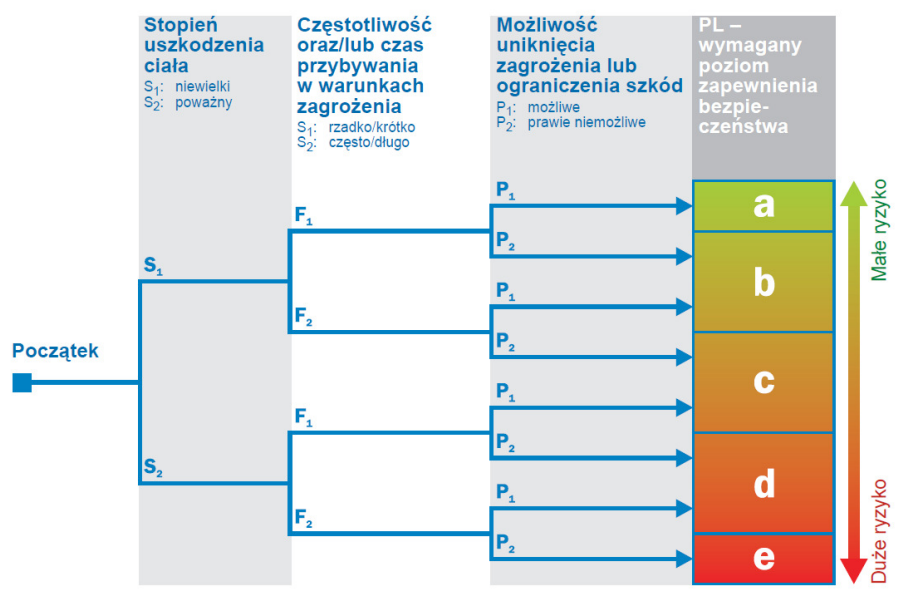

Rysunek 6. Graf ryzyka na podstawie Normy EN ISO 13489 [27] 
Poziom zapewnienia bezpieczeństwa (PL) jest podzielony na pięć dyskretnych poziomów. Zależy on od struktury systemu sterowania, niezawodności zastosowanych elementów, zdolności do rozpoznawania błędów, a także odporności na błędy spowodowane wspólną przyczyną w układach sterowania. Przy określaniu ciężkości urazów uwzględnia się najczęściej spotykane następstwa wypadków i procesy leczenia. Parametr S1 dotyczy takich następstw jak: stłuczenia i/lub rany cięte bez dalszych komplikacji, natomiast S2 - amputacje lub śmierć [5]. Przy ustalaniu czasu i/lub częstotliwości narażenia zaleca się wybór parametru F2, gdy człowiek jest często lub ciągle narażony. Dotyczy to sytuacji, gdy za-chodzi konieczność regularnego się gania do strefy niebezpiecznej np. podczas po dawania i/lub odbioru materiału. Parametr F1 wybieramy gdy dostęp do strefy niebezpiecznej jest wymagany od czasu do czasu. Przy doborze parametru określającego możliwość zapobiegania zagrożeniom (P) istotna jest wiedza na temat zagrożenia i możliwości pod jęcia odpowiednich działań zabezpieczających przed wypadkiem. Duże znaczenie ma możliwość zidentyfikowania zagrożenia (np. na podstawie jego cech fizycznych, a nie tylko za pomocą wskaźników), wyszkolenie i doświadczenie obsługi, szybkość po wstawania zagrożenia, możliwość przeciwdziałania zagrożeniu (ucieczka, interwencja osób trzecich), doświadczenie związane z przebiegiem procesu. Parametr P1 wybieramy, gdy istnieje możliwość uniknięcia wypadku lub znaczącego ograniczenia jego skutków, natomiast parametr P2, gdy uniknięcie zagrożenia jest prawie nie możliwe. Norma ISO 13849-1, definiuje wymagania dotyczące projektowania i wykonania elementów systemów sterowania związanych z bezpieczeństwem. Norma ta znajduje zastosowanie w najważniejszych dziedzinach technologicznych takich jak: hydraulika, pneumatyka, mechanika, elektryka, elektronika, elektronika programowalna.

\section{Określenie funkcji maszyny przeznaczonej do sortowania odpadów zmieszanych}

Tabela 5. Określenie funkcji maszyny zgodnie z wytycznymi [1-4]

\begin{tabular}{|l|l|}
\hline \multicolumn{1}{|c|}{$\begin{array}{l}\text { Wykonywane czynności } \\
\text { (Czas/gęstość ingerencji) }\end{array}$} & \multicolumn{1}{|c|}{ Zastosowane środki bezpieczeństwa } \\
& \\
\hline $\begin{array}{l}\text {-Zasilanie podajnika maszyny odpadami } \\
\text { zmieszanymi , bez wkładania rąk do strefy } \\
\text { niebezpiecznej E=10 }\end{array}$ & -Osłony stałe \\
-Prace serwisowe, mechanika, elektryka, & -Osłona nadzorowana w PL e \\
E=2 & -Odcięcie pneumatyki w PL e \\
& -Zatrymanie realizowane jest w kat 0 \\
& $\begin{array}{l}\text {-Zespół przygotowania powietrza z ręcznym } \\
\text { zaworem odcinającym (automatyczny spust) }\end{array}$ \\
\hline
\end{tabular}

Na podstawie powyższej tablicy zostały określone funkcje maszyny, czynności operatora oraz zastosowane środki bezpieczeństwa takie jak na przykład osłony stałe, osłony nadzorowane przez system sterowania w wysokiej kategorie bezpieczeństwa. 
Tabela 6. Określenie funkcji maszyny

\begin{tabular}{|c|c|c|c|c|}
\hline \multicolumn{5}{|c|}{ Ocena ryzyka pierwotnego (bez uwzględniania zastosowanych środków ochronnych) } \\
\hline $\begin{array}{c}\text { Wskaźnik } \\
\text { Ciężkości } \\
\text { urazu } \\
{[\mathrm{S}]}\end{array}$ & $\begin{array}{l}\text { Ekspozycja } \\
{[\mathrm{E}]}\end{array}$ & $\begin{array}{l}\text { Poziom skuteczności } \\
\text { nadzorowania } \\
\text { zagrożeń }[\mathrm{A}]\end{array}$ & $\begin{array}{c}\text { Wskaźnik } \\
\text { poziomu } \\
\text { ryzyka } \\
\text { [WPR] }\end{array}$ & $\begin{array}{c}\text { Wymagalny } \\
\text { poziom PL r wg } \\
\text { PN-EN ISO } \\
13849-1 \\
\end{array}$ \\
\hline 7 & 10 & 5 & 350 & PL d \\
\hline \multicolumn{5}{|c|}{$\begin{array}{l}\text { Wg przeprowadzonej oceny ryzyka systemy bezpieczeństwa powinny być realizowane w } \\
\text { min KAT3, PL d wg PN-EN 60204-1 i PN-EN ISO } 13849\end{array}$} \\
\hline
\end{tabular}

$\mathrm{Na}$ podstawie powyższej tabeli został określony poziom ryzyka (WPR) oraz wymagany poziom zapewnienia bezpieczeństwa. Wskaźniki ciężkości urazu, ekspozycji oraz skuteczności nadzorowania zagrożeń zostały dobrane na podstawie tab. 1, tab. 2, tab. 3 .

Tabela 7. Zagrożenia mechaniczne dla normalnej pracy urzadzenia - zagrożenia mechaniczne

\begin{tabular}{|c|c|c|c|c|c|}
\hline \multicolumn{6}{|c|}{ Zagrożenia mechaniczne - NORMALNA PRACA } \\
\hline $\begin{array}{c}\text { Źródło } \\
\text { zagrożenia }\end{array}$ & $\begin{array}{c}\text { Skutki } \\
\text { zagrożenia }\end{array}$ & $\begin{array}{l}\text { Rozwiązanie } \\
\text { Konstrukcyjne } \\
\text { (nazwa + opis) }\end{array}$ & $\begin{array}{l}\text { Wskaźnik } \\
\text { poziomu } \\
\text { ryzyka } \\
\text { (WPR) }\end{array}$ & $\begin{array}{l}\text { Parametry } \\
\text { zagrożenia }\end{array}$ & $\begin{array}{c}\text { Poziom } \\
\text { ryzyka }\end{array}$ \\
\hline $\begin{array}{c}\text { Ruch } \\
\text { narzędzia } \\
\text { obróbczego } \\
\text { podczas } \\
\text { spiętrzania }\end{array}$ & $\begin{array}{c}\text { Skaleczenie } \\
\text { Cięcie lub } \\
\text { odcięcie } \\
\text { zmiażdżenie }\end{array}$ & $\begin{array}{c}\text { Wyłącznik } \\
\text { awaryjny PL e } \\
\text { Osłony } \\
\text { nadzorowane } \\
\text { PL e }\end{array}$ & 49 & $\begin{array}{c}S=7 \\
E=10 \\
P=0,7\end{array}$ & $\begin{array}{c}\text { Niskie } \\
\text { Akceptowalne }\end{array}$ \\
\hline $\begin{array}{c}\text { Wyrzucenie } \\
\text { obrabianego } \\
\text { materiału }\end{array}$ & Uderzenie & $\begin{array}{c}\text { Osłony } \\
\text { nadzorowane } \\
\text { PLe e }\end{array}$ & 21 & $\begin{array}{c}S=3 \\
E=10 \\
P=0,7\end{array}$ & $\begin{array}{c}\text { Niskie } \\
\text { Akceptowalne }\end{array}$ \\
\hline $\begin{array}{l}\text { Wymiana } \\
\text { szczęk }\end{array}$ & $\begin{array}{c}\text { Skaleczenie, } \\
\text { stłuczenie }\end{array}$ & $\begin{array}{c}\text { Odcięcie } \\
\text { powietrza } \\
\text { podczas } \\
\text { wymiany } \\
\text { narzędzia }\end{array}$ & 12,6 & $\begin{array}{c}S=3 \\
E=6 \\
P=0,7\end{array}$ & $\begin{array}{l}\text { Bardzo Niskie } \\
\text { Akceptowalne }\end{array}$ \\
\hline
\end{tabular}


Tabela 8. Zagrożenia elektryczne dla normalnej pracy urządzenia - zagrożenia elektryczne

\begin{tabular}{|c|c|c|c|c|c|}
\hline \multicolumn{7}{|c|}{ Zagrożenia elektryczne - NORMALNA PRACA } \\
\hline $\begin{array}{c}\text { Źródło } \\
\text { zagrożenia }\end{array}$ & $\begin{array}{c}\text { Skutki } \\
\text { zagrożeń }\end{array}$ & $\begin{array}{c}\text { Rozwiązanie } \\
\text { konstrukcyjne } \\
\text { (nazwa }+ \\
\text { opis) }\end{array}$ & $\begin{array}{c}\text { Wskaźnik } \\
\text { poziomu } \\
\text { ryzyka }\end{array}$ & $\begin{array}{c}\text { Parametry } \\
\text { zagrożeń }\end{array}$ & $\begin{array}{c}\text { Poziom } \\
\text { ryzyka }\end{array}$ \\
\hline $\begin{array}{c}\text { Porażenie } \\
\text { prądem } \\
\text { elektrycznym }\end{array}$ & Porażenie & $\begin{array}{c}\text { Piktogramy } \\
\text { Instalacja } \\
\text { elektryczna } \\
\text { zgodna z PN- } \\
\text { EN 60204-1 }\end{array}$ & 14 & $\begin{array}{c}\mathrm{S}=10 \\
\mathrm{E}=2 \\
\mathrm{P}=0,7\end{array}$ & $\begin{array}{c}\text { Bardzo Niskie } \\
\text { Akceptowalne }\end{array}$ \\
\hline
\end{tabular}

Analiza ryzyka dla prac serwisowych urządzenia

Tabela 9. Zagrożenia mechaniczne dla prac serwisowych-zagrożenia mechaniczne

\begin{tabular}{|c|c|c|c|c|c|}
\hline \multicolumn{7}{|c|}{ Zagrożenia mechaniczne - PRACE SERWISOWE } \\
\hline $\begin{array}{c}\text { Żródło } \\
\text { zagrożenia }\end{array}$ & $\begin{array}{c}\text { Skutki } \\
\text { zagrożenia }\end{array}$ & $\begin{array}{c}\text { Rozwiązanie } \\
\text { Konstrukcyjne } \\
\text { (nazwa + opis) }\end{array}$ & $\begin{array}{c}\text { Wskaźnik } \\
\text { poziomu } \\
\text { ryzyka } \\
\text { (WPR) }\end{array}$ & $\begin{array}{c}\text { Parametry } \\
\text { zagrożenia }\end{array}$ & $\begin{array}{c}\text { Poziom } \\
\text { ryzyka }\end{array}$ \\
\hline $\begin{array}{c}\text { Ruch } \\
\text { narzędzia } \\
\text { obróbczego } \\
\text { podczas } \\
\text { spiętrzania }\end{array}$ & $\begin{array}{c}\text { Skaleczenie } \\
\text { Cięcie lub } \\
\text { odcięcie } \\
\text { zmiażdżenie }\end{array}$ & $\begin{array}{c}\text { Wyłącznik } \\
\text { awaryjny PL e } \\
\text { Osłony } \\
\text { nadzorowane } \\
\text { PL e }\end{array}$ & 42 & $\begin{array}{c}\mathrm{S}=7 \\
\mathrm{E}=2 \\
\mathrm{P}=3\end{array}$ & $\begin{array}{c}\text { Niskie } \\
\text { Akceptowalne }\end{array}$ \\
\hline
\end{tabular}

Tabela 10. Zagrożenia elektryczne dla prac serwisowych - zagrożenia elektryczne

\begin{tabular}{|c|c|c|c|c|c|}
\hline \multicolumn{6}{|c|}{ Zagrożenia mechaniczne - PRACE SERWISOWE } \\
\hline $\begin{array}{c}\text { Źródło } \\
\text { zagrożenia }\end{array}$ & $\begin{array}{c}\text { Skutki } \\
\text { zagrożenia }\end{array}$ & $\begin{array}{l}\text { Rozwiązanie } \\
\text { Konstrukcyjne } \\
\text { (nazwa + opis) }\end{array}$ & $\begin{array}{l}\text { Wskaźnik } \\
\text { poziomu } \\
\text { ryzyka } \\
\text { (WPR) }\end{array}$ & $\begin{array}{l}\text { Parametry } \\
\text { zagrożenia }\end{array}$ & Poziom ryzyka \\
\hline $\begin{array}{c}\text { Niekontrolo } \\
\text { wany wzrost } \\
\text { ciśnienia }\end{array}$ & $\begin{array}{c}\text { Skaleczenie, } \\
\text { efekt bicza, } \\
\text { powietrze } \\
\text { pod } \\
\text { wysokim } \\
\text { ciśnieniem }\end{array}$ & $\begin{array}{l}\text { Ogranicznik } \\
\text { ciśnienia } \\
\text { Instalacja } \\
\text { pneumatyczna } \\
\text { zgodna z PN- } \\
\text { ISO } 4414\end{array}$ & 30 & $\begin{array}{l}S=5 \\
E=2 \\
P=3\end{array}$ & $\begin{array}{c}\text { Niskie } \\
\text { Akceptowalne }\end{array}$ \\
\hline
\end{tabular}


Tabela 11. Karta oceny ryzyka zawodowego

\begin{tabular}{|c|c|c|c|c|}
\hline \multicolumn{5}{|c|}{ Karta oceny ryzyka zawodowego } \\
\hline \multicolumn{2}{|c|}{$\begin{array}{l}\text { Karta oceny } \mathrm{Nr} \\
\text { ryzyka zawodowego } \\
\text { na stanowisku }\end{array}$} & \multicolumn{3}{|c|}{$\begin{array}{c}\text { Metoda oceny ryzyka zawodowego: } \\
\text { Risk score }\end{array}$} \\
\hline \multicolumn{2}{|c|}{$\begin{array}{l}\text { Operator sortownika } \\
\text { wielofrakcyjnego }\end{array}$} & \multicolumn{3}{|c|}{ Lokalizacja stanowiska: Zakład usług komunalnych } \\
\hline \multicolumn{5}{|c|}{ Opis stanowiska } \\
\hline \multicolumn{5}{|c|}{$\begin{array}{l}\text { Hala usytuowana na parterze powierzchnia gumowa, oświetlenie spełniają wymagania } \\
\text { prawa; wentylacja grawitacyjna }\end{array}$} \\
\hline \multicolumn{5}{|c|}{ Wykonywane czynności } \\
\hline \multicolumn{5}{|c|}{$\begin{array}{ll}\text { 1. } & \text { Obsługa urządzenia na stanowisku operatorskim } \\
\text { 2. } & \text { Obsługa wialni } \\
\text { 3. } & \text { Obsługa pomocniczego taśmociągu magnetycznego } \\
\text { 4. } & \text { Obsługa głównego taśmociągu wykorzystującego zjawisko prądów wirowych }\end{array}$} \\
\hline \multicolumn{5}{|c|}{ Stosowane materiały i środki pracy } \\
\hline \multicolumn{5}{|c|}{ 1. Zmieszane frakcje Obsługa maszyny } \\
\hline \multicolumn{5}{|c|}{ Osoby pracujące na stanowisk } \\
\hline \multicolumn{5}{|l|}{ Operator } \\
\hline \multicolumn{5}{|c|}{$\begin{array}{l}\text { Wymagany poziom wykształcenia, doświadczenia I zdolności użytkownika oraz wymagane } \\
\text { uprawnienia }\end{array}$} \\
\hline \multicolumn{5}{|c|}{ średnie, szkolenie z obsługi maszyny, kurs BHP } \\
\hline \multicolumn{5}{|c|}{ Inne wymagania dotyczące osób zatrudnionych na stanowisku } \\
\hline \multicolumn{5}{|c|}{ Osoba nie może posiadać rozrusznika serca } \\
\hline \multicolumn{5}{|c|}{ Niedogodności i niebezpieczne zdarzenia wykryte w czasie dotychczasowej pracy } \\
\hline \multicolumn{5}{|l|}{ brak } \\
\hline \multicolumn{5}{|c|}{ Wypadki i choroby zawodowe } \\
\hline \multicolumn{5}{|l|}{ Nie było } \\
\hline \multicolumn{5}{|c|}{ Zespół oceniający ryzyko zawodowe } \\
\hline Data oceny & 17.03 .2021 & $\begin{array}{l}\text { Proponow } \\
\text { następnej }\end{array}$ & & 17.03 .2022 \\
\hline Skład zespo & & $\begin{array}{l}\text { Imię I } \\
\text { nazwisko }\end{array}$ & & \\
\hline Przewodnicz & & mgr inż. $\mathrm{P}$ & Tami & \\
\hline Członek & & Iga Drobir & onra & \\
\hline
\end{tabular}


Tabela 12. Karta analizy ryzyka zawodowego na stanowisku operatora maszyny sortujacej

\begin{tabular}{|c|c|c|c|c|c|c|c|c|}
\hline \multicolumn{9}{|c|}{ Karta analizy ryzyka zawodowego } \\
\hline Lp. & Zagrożenie & $\begin{array}{l}\text { Źródło zagrożenia przy } \\
\text { jakiej pracy występuje }\end{array}$ & $\begin{array}{l}\text { Możliwy skutek } \\
\text { (uraz, } \\
\text { pogorszenie } \\
\text { stanu zdrowia, } \\
\text { choroba) }\end{array}$ & Skutki & Ekspozycja & Prawdopodobieństwo & Ryzyko & $\begin{array}{l}\text { Sposoby } \\
\text { zmniejszania } \\
\text { ryzyka }\end{array}$ \\
\hline 1 & $\begin{array}{c}\text { Ostre } \\
\text { krawędzie i } \\
\text { powierzchnie }\end{array}$ & $\begin{array}{l}\text { Materiały poddawane } \\
\text { sortowaniu }\end{array}$ & Zranienia rąk & $\begin{array}{l}\text { Małe } \\
S=1\end{array}$ & $\begin{array}{l}\text { Częsta(codziennie) } \\
\mathrm{E}=6\end{array}$ & $\begin{array}{c}\text { Mało } \\
\text { prawdopodobne, } \\
\text { możliwe } \\
\mathrm{P}=1\end{array}$ & $\begin{array}{l}\text { Akceptowalne } \\
\quad \mathrm{R}=6\end{array}$ & $\begin{array}{l}\text { Wzmożona } \\
\text { uwaga }\end{array}$ \\
\hline 2 & Pożar & $\begin{array}{l}\text { Zaprószenie ognia, } \\
\text { instalacja elektryczna, } \\
\text { urządzenia elektryczne }\end{array}$ & $\begin{array}{l}\text { Poparzenie, } \\
\text { śmierć }\end{array}$ & $\begin{array}{c}\text { Bardzo } \\
\text { duże } \\
\mathrm{S}=15\end{array}$ & $\begin{array}{c}\text { Częsta(codziennie) } \\
\text { E }=6\end{array}$ & $\begin{array}{l}\text { Możliwe do } \\
\text { pomyślenia } \\
\mathrm{P}=0,2\end{array}$ & $\begin{array}{l}\text { Akceptowalne } \\
\mathrm{R}=18\end{array}$ & $\begin{array}{c}\text { Przestrzeganie } \\
\text { przepisów ppoż., } \\
\text { sprawny sprzęt } \\
\text { uwaga } \\
\end{array}$ \\
\hline 3 & $\begin{array}{c}\text { Prąd } \\
\text { elektryczny }\end{array}$ & $\begin{array}{l}\text { Urządzenia zasilane } \\
\text { prądem elektrycznym }\end{array}$ & $\begin{array}{c}\text { Porażenie } \\
\text { prądem, śmierć }\end{array}$ & $\begin{array}{l}\text { Bardzo } \\
\text { duże } \\
\mathrm{S}=15\end{array}$ & $\begin{array}{l}\text { Częsta(codziennie) } \\
\text { E }=6\end{array}$ & $\begin{array}{c}\text { Tylko sporadycznie } \\
\text { możliwe } \\
P=0,5\end{array}$ & $\begin{array}{l}\text { Akceptowalne } \\
\quad \mathrm{R}=45\end{array}$ & $\begin{array}{c}\text { Pomiary, } \\
\text { sprawna } \\
\text { instalacja, } \\
\text { sprawny sprzęt, } \\
\text { uwaga }\end{array}$ \\
\hline 4 & $\begin{array}{l}\text { Uderzenie o } \\
\text { nie-ruchome } \\
\text { przedmioty }\end{array}$ & $\begin{array}{c}\text { Materiały, sprzęty } \\
\text { znajdujące się na hali }\end{array}$ & $\begin{array}{l}\text { Potłuczenie, } \\
\text { guzy, siniaki }\end{array}$ & $\begin{array}{l}\text { Małe } \\
S=1\end{array}$ & $\begin{array}{l}\text { Częsta(codziennie) } \\
\text { E }=6\end{array}$ & $\begin{array}{c}\begin{array}{c}\text { Praktycznie możliwe } \\
\text { P }=3\end{array}\end{array}$ & $\begin{array}{l}\text { Akceptowalne } \\
\mathrm{R}=18\end{array}$ & $\begin{array}{l}\text { Uwaga, } \\
\text { utrzymanie } \\
\text { porządku }\end{array}$ \\
\hline 5 & $\begin{array}{c}\text { Uderzenie } \\
\text { przez } \\
\text { spadające } \\
\text { przedmioty }\end{array}$ & Materiały sortowane & $\begin{array}{l}\text { Pothuczenia, } \\
\text { skaleczenia }\end{array}$ & $\begin{array}{l}\text { Srednie } \\
\mathrm{S}=3\end{array}$ & $\begin{array}{l}\text { Częsta(codziennie) } \\
\qquad \mathrm{E}=6\end{array}$ & $\begin{array}{c}\text { Mało } \\
\text { prawdopodobne, } \\
\text { możliwe } \\
\mathrm{P}=1\end{array}$ & $\begin{array}{l}\text { Akceptowalne } \\
\quad \mathrm{R}=18\end{array}$ & Uwaga \\
\hline
\end{tabular}


Tabela 12. cd. Karta analizy ryzyka zawodowego na stanowisku operatora maszyny sortujacej

\begin{tabular}{|c|c|c|c|c|c|c|c|c|}
\hline \multicolumn{9}{|c|}{ Karta analizy ryzyka zawodowego } \\
\hline Lp. & Zagrożenie & $\begin{array}{l}\text { Źródło zagrożenia } \\
\text { przy jakiej pracy } \\
\text { występuje }\end{array}$ & $\begin{array}{l}\text { Możliwy skutek } \\
\text { (uraz, } \\
\text { pogorszenie } \\
\text { stanu zdrowia, } \\
\text { choroba) }\end{array}$ & Skutki & Ekspozycja & Prawdopodobieństwo & Ryzyko & $\begin{array}{l}\text { Sposoby } \\
\text { zmniejszania } \\
\text { ryzyka }\end{array}$ \\
\hline 6 & $\begin{array}{l}\text { Upadek na tym } \\
\text { samym } \\
\text { poziomie }\end{array}$ & Sliskie podłogi & $\begin{array}{l}\text { Złamania kości, } \\
\text { potłuczenia, } \\
\text { zwichnięcia }\end{array}$ & $\begin{array}{c}\text { Srednie } \\
\mathrm{S}=3\end{array}$ & $\begin{array}{c}\text { Częsta(codziennie) } \mathrm{E} \\
=6\end{array}$ & $\begin{array}{l}\text { Mało prawdopodobne, } \\
\text { możliwe } \\
\mathrm{P}=1\end{array}$ & $\begin{array}{l}\text { Akceptowalne } \\
\mathrm{R}=18\end{array}$ & $\begin{array}{c}\text { Czyste i } \\
\text { nieśliskie } \\
\text { podłogi, uwaga }\end{array}$ \\
\hline 7 & $\begin{array}{c}\text { Zranienie przez } \\
\text { elementy } \\
\text { ruchome } \\
\text { maszyny }\end{array}$ & $\begin{array}{l}\text { Włączone, } \\
\text { Niezabezpieczone } \\
\text { urządzenie }\end{array}$ & $\begin{array}{l}\text { Złamania kości, } \\
\text { utrata części } \\
\text { kończyny }\end{array}$ & $\begin{array}{c}\text { Duże } \\
S=7\end{array}$ & $\begin{array}{c}\text { Częsta(codziennie) E } \\
=6\end{array}$ & $\begin{array}{l}\text { tylko sporadycznie } \\
\text { możliwe } \\
\text { P=1 }\end{array}$ & $\begin{array}{l}\text { Akceptowalne } \\
\mathrm{R}=18\end{array}$ & Uwaga \\
\hline 8 & $\begin{array}{c}\text { Duży hałas } \\
\text { generowany } \\
\text { przez maszynę }\end{array}$ & $\begin{array}{l}\text { Hałas generowany } \\
\text { przez maszynę }\end{array}$ & $\begin{array}{c}\text { Utrata bądź } \\
\text { pogorszenie się } \\
\text { słuchu }\end{array}$ & $\begin{array}{c}\text { Duże } \\
S=7\end{array}$ & $\begin{array}{c}\text { Częsta(codziennie) E } \\
=6\end{array}$ & $\begin{array}{l}\text { Całkiem możliwe } \\
\mathrm{P}=6\end{array}$ & $\begin{array}{c}\text { Akceptowalne } \\
\mathrm{R}=18\end{array}$ & $\begin{array}{c}\text { Noszenie } \\
\text { słuchawek } \\
\text { ochronnych }\end{array}$ \\
\hline 9 & $\begin{array}{l}\text { Wystawienie } \\
\text { na działanie } \\
\text { pola } \\
\text { magnetycznego }\end{array}$ & $\begin{array}{c}\text { Zagrożenie dla } \\
\text { osoby z } \\
\text { rozrusznikiem serca }\end{array}$ & $\begin{array}{c}\text { Zaburzenie } \\
\text { pracy } \\
\text { rozrusznika, } \\
\text { śmierć }\end{array}$ & $\begin{array}{c}\text { Bardzo } \\
\text { duża } \\
\mathrm{S}=15\end{array}$ & $\begin{array}{l}\text { Stała } \\
\mathrm{E}=10\end{array}$ & $\begin{array}{c}\text { Tylko sporadycznie } \\
\text { możliwe } \\
\mathrm{P}=0,5\end{array}$ & $\begin{array}{c}\text { Akceptowalne } \\
\mathrm{R}=1,5\end{array}$ & $\begin{array}{c}\text { Stosowanie się } \\
\text { do znaków } \\
\text { ostrzegawczych } \\
\text { i } \\
\text { informacyjnych }\end{array}$ \\
\hline
\end{tabular}


Na podstawie przeprowadzonej analizy ryzyka zasadowego stwierdzono, że praca na stanowisku operatora maszyny sortującej jest bezpieczna przy przestrzeganiu podstawowych warunków BHP panujących w przedsiębiorstwie oraz przy wyposażeniu w środki ochrony indywidualnej takiej jak odpowiednia odzież ochronna, ochronniki słuchu, okulary, rękawiczki.

\section{Wnioski}

Wymagania dotyczące zabezpieczenia maszyn ulegają zmianom wraz z rozwojem systemów automatyki i sterowania. Źle zaprojektowane systemy bezpieczeństwa mogą powodować utrudnienia przy obsłudze maszyn i powodować, że całkowicie z nich rezygnowano. Współcześnie dzięki innowacyjnej technice można integrować osłony i urządzenia ochronne w procesie pracy. Tym samym nie stanowią one już przeszkody dla operatora, a często wspomagają nawet produktywność. Z tego powodu nie da się obecnie zrezygnować z niezawodnych i zintegrowanych w procesie pracy osłon i urządzeń ochronnych. Przy projektowaniu systemów bezpieczeństwa maszyn wykorzystuje się coraz bardziej zaawansowane narzędzia do walidacji poprawności zastosowanych rozwiązań technicznych. Projektowanie rozwiązań zwiększających poziom bezpieczeństwa maszyn wymaga wprowadzenia założeń obejmujących integrację maszyny z operatorem. Bezpieczeństwo ludzi zależy w dużej mierze od prawidłowego stosowania Dyrektyw i Norm. Krajowe przepisy prawa w państwach Europy zostały ujednolicone poprzez zastosowanie dyrektyw europejskich, np. dyrektywy maszynowej. Dlatego aby zaprojektować bezpieczne urządzenie niezbędne są: doświadczenie oraz kompletna wiedza ekspercka. Bezpieczeństwo jest podstawową potrzebą człowieka. Z badań wynika, że osoby stale narażone na sytuacje stresowe są bardziej podatne na potencjalne zagrożenia oraz wypadki.

\section{LITERATURA}

1. URBANIAK M. (red): Bezpieczeństwo Przemysłowe. Tom 1, Wydawnictwo Akcydens, Warszawa 2009.

2. URBANIAK M. SOSNOWSKI I (red): Bezpieczeństwo przemysłowe Tom 3, Wydanie pierwsze Wydawnictwo Akcydens, Warszawa 2009.

3. Dyrektywa Parlamentu Europejskiego i Rady 2006/42/WE z dnia 17.05.2006 r.

4. Dyrektywa Parlamentu Europejskiego i Rady 2009/104/WE z dnia 16.09.2009 dotycząca minimalnych wymagań w dziedzinie bezpieczeństwa i higieny użytkowania sprzętu roboczego przez pracowników pod czas pracy.

5. Przewodnik Bezpieczne Maszyny - Bezpieczna maszyna w sześciu krokach Wydawnictwo: Sick 2015

6. Norma PN-EN ISO 13857: Bezpieczeństwo maszyn - Odległości bezpieczeństwa uniemożliwiające sięganie kończynami górnymi i dolnymi do stref niebezpiecznych.

7. Norma PN-EN 60204-1: Bezpieczeństwo maszyn - Wyposażenie elektryczne maszyn - Część 1: Wymagania ogólne. 
8. Norma PN-EN 61310-1: Bezpieczeństwo maszyn - Wskazywanie, oznaczanie i sterowanie - Część 1: Wymagania dotyczące sygnałów wizualnych, akustycznych i dotykowych.

9. Norma PN-EN 61310-2: Bezpieczeństwo maszyn - Wskazywanie, oznaczanie i sterowanie - Część 2: Wymagania dotyczące oznaczania.

10. Norma PN-EN 61310-3: Bezpieczeństwo maszyn - Wskazywanie, oznaczanie i sterowanie - Część 3: Wymagania dotyczące umiejscowienia i działania elementów sterowniczych.

11. Norma PN-EN 62061: Bezpieczeństwo maszyn - Bezpieczeństwo funkcjonalne elektrycznych, elektronicznych i programowalnych elektronicznych systemów sterowania związanych z bezpieczeństwem.

12. Norma PN-EN ISO 12100: Bezpieczeństwo maszyn - Ogólne zasady projektowania - Ocena ryzyka i zmniejszenie ryzyka.

13. Norma PN-EN ISO 13849-1: Bezpieczeństwo maszyn - Elementy systemów sterowania związane $\mathrm{z}$ bezpieczeństwem - Część 1: Ogólne zasady projektowania.

14. Norma PN-EN ISO 13850: Bezpieczeństwo maszyn - Zatrzymania awaryjne Zasady projektowania.

15. Norma PN-EN ISO 13855: Bezpieczeństwo maszyn - Umiejscowienie wyposażenia ochronnego ze względu na prędkości zbliżania części ciała człowieka.

16. Norma PN-EN ISO 4413: Bezpieczeństwo maszyn - Wymagania bezpieczeństwa dotyczące układów hydraulicznych i pneumatycznych i ich elementów - Hydraulika.

17. Norma PN-EN ISO 4414: Bezpieczeństwo maszyn - Wymagania dotyczące bezpieczeństwa układów hydraulicznych i pneumatycznych i ich elementów Pneumatyka.

18. Nowe podejście do bezpieczeństwa maszyn: PN-EN ISO 13849-1 Wydawnictwo: Schmersal 2018.

19. Norma PN-EN ISO 13849-2: Bezpieczeństwo maszyn - Elementy systemów sterowania związane z bezpieczeństwem -- Część 2: Walidacja.

20. Norma PN-EN ISO 14119: Bezpieczeństwo maszyn - Urządzenia blokujące sprzężone z osłonami - Zasady projektowania i doboru..

21. Serwis internetowy: https://cdn.sick.com/media/docs/8/98/398/Special_information_Guide_for_Saf e_Machinery_pl_IM0 062398.PDF data dostępu (17 kwietnia 2020r)

22. Terminologia i standardy w bezpieczeństwie maszyn - Wydawnictwo: Siemens

23. Serwis internetowy: https://publikacje.siemensinfo.com/pdf/31/Przeka\%C5\%BAniki\%20bezpiecze\%C5\%84stwa \%20-\%20przyk\% C5\%82ady\%20aplikacji.pdf data dostępu (17 kwietnia 2020r)

24. Serwis internetowy: http://docplayer.pl/docs-images/40/4432620/images/page_2.jpg data dostępu (12.04.2020r)

25. NEUDÖRFER A.: Konstruieren sicherheitsgerechter Produkte (Konstruowanie bezpiecznych produktów), Springer-Verlag, Berlin et al., ISBN 978-3-64233889-2 (5. wydanie 2013). 
26. Serwis internetowy:

https://sick.data.continum.net/media/dox/8/98/348/Special_information_Przew odnik_Bezpieczne_Maszyny_pl_IM0062398.PDF data dostępu (12.04.2020r).

27. Serwis internetowy:

https://sick.data.continum.net/media/dox/8/98/348/Special_information_Przew odnik_Bezpieczne_Maszyny_pl_IM0062398.PDF 12.04.2021r. 